\title{
Pengaruh Motivasi, Penghargaan Finansial, Pelatihan Profesional, Pertimbangan Pasar Kerja, Lingkungan Pada Karir Akuntan Publik
}

\author{
Putu Nanda Rahayu ${ }^{1}$ \\ Nyoman Wijana Asmara Putra ${ }^{2}$ \\ ${ }^{1,2}$ Fakultas Ekonomi dan Bisnis, Universitas Udayana (Unud), Bali, Indonesia \\ e-mail: nanda_rahayu35@yahoo.com
}

\begin{abstract}
ABSTRAK
Tujuan penelitian ini adalah untuk mendapatkan bukti empiris pengaruh motivasi karir, motivasi ekonomi, penghargaan finansial, pelatihan profesional, pertimbangan pasar kerja, lingkungan teman dan keluarga pada pemilihan karir sebagai akuntan publik. Metode Penentuan sampel pada penelitian ini menggunakan teknikpurposive sampling. Sampel penelitian ini adalah mahasiswa jurusan akuntansi reguler FEB Udayana angkatan 2015 yang berjumlah 142 orang. Metode pengumpulan data yang digunakan dengan metode angket berupa kuesioner. Teknik analisis data yang digunakan adalah uji asumsi klasik dan analisis regresi linear berganda. Berdasarkan hasil analisis ditemukan bahwa motivasi yang meliputi motivasi karir dan ekonomi, penghargaan finansial, pelatihan profesional, pertimbangan pasar kerja, lingkungan teman dan keluarga berpengaruh positif terhadap pemilihan karir sebagai akuntan publik.

Kata kunci: Motivasi karir, penghargaan finansial, pelatihan profesional, pertimbangan pasar kerja, lingkungan, dan pemilihan karir akuntan public.
\end{abstract}

\begin{abstract}
The purpose of this study was to obtain empirical evidence of the influence of career motivation, economic motivation, financial rewards, professional training, consideration of the job market, the environment of friends and family in choosing a career as a public accountant. Methods Determination of samples in this study using purposive sampling technique. The sample of this study were regular accounting students at FEB Udayana class of 2015, amounting to 142 people. Data collection methods used with the questionnaire method in the form of a questionnaire. The data analysis technique used is the classic assumption test and multiple linear regression analysis. Based on the results of the analysis it was found that motivation which included career and economic motivation, financial rewards, professional training, consideration of the job market, friend and family environment had a positive effect on career choice as a public accountant.

Keywords: Career motivation, financial rewards, professional training, consideration of the labor market, environment, and selection of a career in public accounting.
\end{abstract}

\section{PENDAHULUAN}

Aspek penting dalam kehidupan manusia dewasa yang sehat adalah karir, dimana dan kapanpun mereka berada. Ketepatan menentukan dan memilih karir mejadi titik penting dalam perjalanan hidup manusia, oleh karenanya karir seseorang berkontribusi besar bagi diri dan merupakan inti dari nilai dasar dan tujuan hidup 
seseorang (Warsitasari \& Astika, 2017). Karir merupakan salah satu tujuan dari individu untuk mencapai jenjang yang lebih tinggi. Beberapa studi mengklaim bahwa mahasiswa setelah lulus biasanya menghadapi dilema dalam membuat keputusan karir (Muhamad, Salleh, \& Nordin, 2016). Dunia kerja untuk jurusan akuntansi ada beberapa pilihan karir yaitu sebagai akuntan publik, akuntan pemerintah, akuntan pendidik, dan akuntan manajemen.

Pilihan tersebut diharapkan akan menjadikan seseorang menjadi profesional dalam bidangnya masing-masing sehingga karir yang diinginkan akan tercapai sesuai dengan harapannya. Akuntansi merupakan bidang studi yang banyak diminati oleh mahasiswa ekonomi saat ini, dan sebagai bentuk peningkatan kualitas dari lulusan akuntansi maka melalui surat Keputusan Menteri Pendidikan Nasional Nomor: 179/U/2001 tentang penyelenggaraan Pendidikan Profesi Akuntansi, dan surat keputusan mendiknas Nomor: 180/P/2001 tentang Pengangkatan Panitia Ahli Persamaan Ijazah Akuntan, serta di tanda tanganinya MOU antara Ikatan Akuntan Indonesia (IAI) dengan Dirjen Dikti Depdiknas atas pelaksanaan pendidikan profesi akuntan, yang pada akhirnya Pendidikan Profesi Akuntasi di Indonesia dapat terealisasi.

Indonesia masih kekurangan sumber daya akuntan publik. Keadaan terebut disebabkan salah satunya karena kurangnya minat mahasiswa yang setelah lulus sarjana untuk berprofesi sebagai akuntan publik (Alfrido, 2014). Alasan lain masih kurannya tenaga akuntan publik adalah biaya pendidikan yang dibutuhkan relatif mahal. Hal ini menyebabkan calon akuntan publik harus mempersiapkan dana dan yang paling penting motivasi yang tinggi dalam belajar. Rencana 
diberlakukannya ASEAN Economic Community (AEC) atau dikenal juga dengan Masyarakat Ekonomi Asean (MEA) pada tahun 2015 menimbulkan tantangan baru bagi Indonesia. Keadaan tersebut menyebabkan posisi yang seharusnya ditempati oleh Akuntan Publik Indonesia justru akan direbut oleh Akuntan Publik Asing (Alimah \& Agustina, 2014).

Pemerintah Indonesia pada bulan Mei 2011, mengeluarkan UU No. 5 Tahun 2011 tentang profesi akuntan publik. Pemerintah secara jelas memperbaharui dan merevisi beberapa peraturan kembali tentang profesi akuntan publik. Profesi akuntansi selalu diminati dalam bisnis, karena semua bisnis perlu menghasilkan informasi keuangan, dan professional akuntansi dapat memproses data keuangan dan menghasilkan informasi keuangan (Pratama, 2017). Peraturan dan kebijakan yang dikeluarkan pemerintah mengenai syarat menjadi seorang akuntan yang harus mengikuti pendidikan profesi akuntan setelah lulus sarjana ekonomi akuntansi, membuat jumlah profesi akuntan meningkat dari tahun ke tahun.

Profesi akuntan pada saat ini memiliki peran penting bagi entitas bisnis, pemerintah, dan masyarakat karena dianggap sebagai salah satu pihak yang mampu memberikan kontribusi besar dalam memecahkan masalah yang mereka hadapi, oleh karena itu, profesi akuntan dituntut untuk dapat menjawab tantangan yang ditimbulkan oleh perusahaan lingkungan, sehingga perkembangan dalam dunia bisnis harus selalu direspon oleh sistem pendidikan akuntansi yang berkualitas dan siap pakai di dunia kerja. Akuntan umumnya diklasifikasikan sebagai profesi gaji yang tinggi (Omar, Zakaria, Ismail, Sin, \& Selvakumar, 2015). Pendidikan akuntansi harus menghasilkan akuntan yang profesional sejalan 
dengan perkembangan kebutuhan akan jasa akuntansi pada abad mendatang (Benny \& Yuskar, 2006) .

Salah satu faktor yang mempengaruhi mahasiswa untuk memilih berkarir sebagai akuntan publik adalah motivasi. Samsuri berpendapat bahwa kurangnya motivasi dari mahasiswa dapat memberikan dampak kesulitan bagi mahasiswa untuk menentukan suatu pilihan (Samsuri, Arifin, \& Hussin, 2016). Kuatnya motivasi yang dimiliki individu akan banyak menentukan terhadap kualitas perilaku yang ditampilkannya, baik dalam konteks belajar, bekerja maupun dalam kehidupan lainnya. Ada beberapa jenis motivasi yang mempengaruhi mahasiswa dalam penelitian karir sebagai akuntan publik, antara lain: motivasi karir untuk meningkatkan jenjang karir, dan motivasi ekonomi untuk meningkatkan penghasilan dan status ekonomi (Diana Sari, 2015).

Teori motivasi yang diungkapkan oleh (Robbins \& Judge, 2008) menyatakan bahwa sikap seorang terbentuk dari tiga komponen yaitu: 1) cognitive component, 2) emotional component, dan 3) behavior componen. Teori pengharapan Vroom mengatakan bahwa penilaian kinerja yang baik akan mendorong imbalan organisasi seperti bonus, kenaikan penghargaan finansial/gaji atau promosi dan imbalan tersebut akan memenuhi sasaran pribadi karyawan tersebut. Penghargaan finansial, pengakuan profesional, nilai-nilai sosial, dan personalitas terdapat perbedaan persepsi dalam pemilihan karir sebagai akuntan (Hutapea, 2016). Sedangkan pelatihan profesional, pertimbangan pasar kerja, lingkungan teman keluarga dan tidak terdapat perbedaan persepsi dalam pemilihan karir sebagai akuntan (Warsitasari \& Astika, 2017). 
Pada penelitian terdahulu banyak yang membahas tentang pengaruh penghargaan finansial terhadap pemilihan karir sebagai akuntan. Seperti pada penelitian (Rahmat \& Zulaikha, 2013), (Chan, 2012), bahwa berpengaruh secara signifikan pada pemilihan karir sebagai akuntan (Warsitasari \& Astika, 2017). Tetapi di dalam penelitian (Merdekawati \& Sulistyawati, 2011) penghargaan finansial tidak berpengaruh terhadap pemilihan karir sebagai akuntan.

Pelatihan profesional dalam penelitian (Rahmat \& Zulaikha, 2013), (Chan, 2012), (Merdekawati \& Sulistyawati, 2011) bahwa berpengaruh secara signifikan terhadap pemilihan karir akuntan. Tetapi di dalam penelitian Febriana (2013) pelatihan profesional tidak berpengaruh terhadap pemilihan karir akuntan (Naraika Naminingsih, 2017).

Teori motivasi yang paling terkenal dan merupakan perintis adalah teori hierarki kebutuhan Abraham Maslow (Venugopalan, 2007:38). Abraham Maslow (1954) yang dikutip oleh (Robbins \& Judge, 2015) mengemukakan mengenai teori motivasi Maslow yaitu Teori Hierarki Kebutuhan. Menurut Maslow dalam (Robbins \& Judge, 2015) teorinya menjelaskan bahwa setiap individu mempunyai beraneka ragam kebutuhan yang dapat mempengaruhi perilaku mereka. Teori ini juga menyebutkan bahwa apabila seseorang memutuskan menerima uang yang cukup untuk suatu pekerjaan dari sebuah organisasi tempatnya bekerja, maka uang tersebut tidak memiliki daya intensitasnya lagi.

Karir merupakan salah satu tujuan dari individu untuk mencapai jenjang yang lebih tinggi. Pilihan karir yang tepat bagi mahasiswa yang telah lulus sangat penting bagi kehidupan dan masa depan mereka nanti (Afaq Ahmed, Sharif, \& 
Ahmad, 2017). Karir tidak hanya menentukan pola pendapatan individu tetapi juga mempengaruhi kepribadian seseorang dan konsep dalam kehidupan (Zotorvie, 2016).

(Mulyadi, 2006). mengatakan bahwa akuntan publik adalah akuntan professional yang menjual jasanya kepada masyarakat, terutama bidang pemeriksaan terhadap laporan keuangan yang dibuat oleh kliennya. Pemeriksaan tersebut terutama ditujukkan untuk memenuhi kebutuhan para kreditur, investor, calon kreditur, calon investor, dan instansi pemerintah (terutama instansi pajak). Akuntan publik melaksanakan empat jenis jasa utama, antara lain: atestesi, perpajakan, konsultasi manajemen, serta jasa akuntansi dan pembukuan dalam (Asmoro, Wijayanti, \& Suhendro, 2016).

Ketentuan mengenai akuntan publik di Indonesia diatur dalam UndangUndang Republik Indonesia Nomor 5 tahun 2011 tentang Akuntan Publik dan Peraturan Menteri Keuangan Nomor 17/PMK.01/2008 tentang jasa Akuntan Publik Indonesia (IAPI), asosiasi profesi yang diakui oleh Pemerintah. Akuntan publik merupakan profesi yang sangat dibutuhkan di Indonesia dan juga dipandang menjanjikan prospek dunia kerja yang cerah akan profesi ini memberikan tantangan intelektual dan pengalaman belajar yang tidak ternilai (Wheeler, 1983).

Motivasi karir adalah keadaan yang menyebabkan manusia tergerak pada arah tujuannya, dalam keterkaitannya dengan lingkungan kerjanya (Lunenburg, 2011), Carl dan Lawrence (2008) dalam (Aryani \& Erawati, 2016) mengemukakan bahwa keefektifan suatu karir tidak hanya ditentukan oleh 
individu saja tetapi juga oleh organisasi itu sendiri yang terlihat dalam empat tahapan karir, yaitu: entry, tahap pengembangan keahlian dan teknis, midcareer years, dan late career.

Penelitian yang dilakukan oleh (Carpenter \& Strawser, 1970) untuk mengetahui kriteria mahasiswa jurusan akuntansi pada tingkat akhir di Pennsylvania State University dalam memilih karir. Hasil penelitian tersebut menunjukkan bahwa sifat pekerjaan, kesempatan promosi, dan gaji awal merupakan tiga karakter terpenting dalam pemilihan karir dalam 11 faktor pekerjaan. Dapat dikatakan bahwa kesempatan kerja dan jumlah pendapatan merupakan faktor penting dalam mempengaruhi keputusan untuk memilih akuntan sebagai karir mereka (Gul et al, 1989; Adam et al, 1994; (Mauldin, Crain, \& Mounce, 2000) dalam (Warsitasari \& Astika, 2017) menyatakan bahwa salah satu penyebab menurutnya jumlah mahasiswa akuntansi selama kurun waktu 1995 hingga 1999 yang mencapai 23\% adalah akibat lebih rendahnya gaji awal pada profesi jika dibandingkan dengan tahun-tahun sebelumnya.

Menurut (Widiatami, 2013) gaji dipertimbangkan data pemilihan karir karena tujuan utama seseorang bekerja adalah untuk memperoleh gaji guna memenuhi kebutuhan fisiologisnya. Dengan bekerja, seseorang akan menghasilkan gaji yang dapat digunakan untuk memenuhi kebutuhan hidupnya. Menurut (Kadarisman, 2012) Penghargaan finansial merupakan salah satu alasan bagi seseorang untuk bekerja dan merupakan alasan yang paling penting diantara yang lain seperti untuk berprestasi, berafiliasi dengan orang lain, mengembangkan diri, atau untuk mengaktualisasikan diri. 
Menurut (Robbins \& Judge, 2015) bahwa terdapat tiga hubungan yang memotivasi individu, salah satunya yaitu hubungan imbalan-sasaran pribadi, hubungan ini menjelaskan sampai sejauh mana imbalan dalam suatu organisasi memenuhi sasaran atau kebutuhan pribadi individu, serta potensi daya tarik imbalan tersebut bagi individu tersebut. Pertimbangan pasar kerja meliputi keamanan kerja dan tersedianya lapangan kerja atau kemudahan mengakses lowongan kerja (Naraika Naminingsih, 2017). Pertimbangan pasar kerja selalu dipertimbangkan mahasiswa dalam pemilihan profesi, karena terpuruknya keadaan perekonomian dan sulitnya mencari kerja, mengakibatkan mahasiswa memperhatikan pasar kerja, baik dalam jangka panjang maupun jangka pendek.

Secara spesifik kewajiban mengenai keselamatan kerja tersebut telah diatur dalam Undang Undang No 1 tahun 1970 yang berlaku tanggal 12 Januari 1970 dalam pasal 3 ayat 1 . Keamanan kerja menjadi faktor yang sangat penting yang harus pikirkan oleh perusahaan. Selain sebagai menjaga dan melindungi para karyawannya juga merupakan sebagai daya tarik lain yang turut diperhitungkan oleh calon karyawan.

Pada peneliti sebelumnya, penelitian yang dilakukan oleh (Warsitasari \& Astika, 2017) yang menggunakan variabel bebas motivasi karir mendapatkan kesimpulan bahwa motivasi karir berpengaruh terhadap pemilihan karir sebagai akuntan publik. Karena dengan adanya motivasi karir akan memberikan dorongan bagi individu untuk mencapai keunggulan karir, meningkatkan keterampilan didalam berkarir juga mengharapkan adanya hasil yang berkualitas tinggi dari 
jenjang karir mereka. Berdasarkan uraian tersebut, maka dapat disimpulkan hipotesis sebagai berikut:

$\mathrm{H}_{1}$ : Motivasi karir berpengaruh positif pada pemilihan karir sebagai akuntan publik.

Motivasi ekonomi merupakan suatu dorongan yang timbul dalam diri seseorang untuk meningkatkan kemampuan pribadi dalam rangka untuk memperoleh penghargaan finansial yang diinginkan (Widyastuti, 2004).

Mahasiswa yang memilih profesi akuntan pemerintahan dan akuntan pendidik lebih mengharapkan dana pensiun dibandingkan dengan mahasiswa yang memilih profesi akuntan perusahaan dan akuntan publik. Hasil penelitian yang dilakukan oleh (Warsitasari \& Astika, 2017) menyatakan bahwa variabel motivasi ekonomi berpengaruh signifikan dalam pemilihan karir sebagai akuntan publik. Berdasarkan uraian tersebut, maka dapat disimpulkan hipotesis sebagai berikut:

$\mathrm{H}_{2:}$ Motivasi Ekonomi berpengaruh positif pada pemilihan karir sebagai akuntan publik.

Penghargaan finansial merupakan reward dalam bentuk nilai mata uang yang biasanya diberikan sebagai bentuk imbalan timbal balik atas pemberian jasa, tenaga, usaha dan manfaat seseorang dalam suatu ikatan pekerjaan. Teori pengharapan Vroom mengatakan bahwa penilaian kinerja yang baik akan mendorong imbalan organisasi seperti bonus, kenaikan penghargaan finansial/gaji atau promosi dan imbalan tersebut akan memenuhi sasaran pribadi karyawan tersebut.

Penelitian terdahulu menyatakan bahwa variabel gaji atau penghargaan finansial berpengaruh signifikan dalam pemilihan karir sebagai akuntan publik 
(Yanti, 2014). Berdasarkan uraian tersebut, maka dapat disimpulkan hipotesis sebagai berikut:

$\mathrm{H}_{3}$ : Penghargaan finansial berpengaruh positif pada pemilihan karir sebagai akuntan publik.

Karir sebagai akuntan dianggap lebih memerlukan pelatihan kerja profesional guna meningkatkan kemampuan profesional dan mendapatkan pengalaman kerja yang bervariasi (Rahayu, 2003). Hasil penelitian yang dilakukan oleh (Rahmat \& Zulaikha, 2013) yang menggunakan variabel bebas pelatihan professional mendapatkan kesimpulan bahwa motivasi karir berpengaruh terhadap pemilihan karir sebagai akuntan publik. Berdasarkan uraian tersebut, maka dapat disimpulkan hipotesis sebagai berikut.

$\mathrm{H}_{4}$ : Pelatihan Profesional berpengaruh positif terhadap pemilihan karir sebagai akuntan publik.

Menurut Robbins (2011) menyatakan bahwa salah satu dari komponen pembentukan sikap seseorang yaitu Cognitive Component yang merupakan keyakinan dari informasi yang dimiliki oleh seseorang mempengaruhi sikap seseorang terhadap profesi yang akan dijalani.

Hasil penelitian terdahulu yang dilakukan oleh (Utami, 2016) menunjukkan bahwa pertimbangan pasar kerja memiliki pengaruh signifikan terhadap pemilihan karir mahasiswa akuntansi sebagai akuntan publik. Penelitian yang dilakukan (Carpenter \& Strawser, 1970) dalam (Rahayu, 2003) menemukan bahwa pertimbangan pasar kerja menempati peringkat tertinggi antara faktor-faktor yang mempengaruhi pilihan profesi mahasiswa yang akan datang. Berdasarkan uraian tersebut, maka dapat disimpulkan hipotesis sebagai berikut: 
$\mathrm{H}_{5}$ : Pertimbangan pasar kerja berpengaruh positif terhadap pemilihan karir menjadi akuntan publik.

Teman dan keluarga merupakan orang terdekat dari mahasiswa akuntansi dalam menjadi kehidupan sehari-hari di lingkungannya. Kelompok teman sebaya adalah sekelompok teman yang mempunyai ikatan emosional yang kuat dan siswa dapat berinteraksi, bergaul, bertukar pikiran, dan pengalaman dalam memberikan perubahan dan pengembangan dalam kehidupan sosial dan pribadinya Usman dalam (Naraika Naminingsih, 2017).

Tafsir dalam (Naraika Naminingsih, 2017) mengatakan orang tua adalah pendidik utama dan pertama dalam hal menanamkan keimanan bagi anaknya. Pengaruh keluarga dan teman yang dimaksud adalah dalam bentuk rujukan yang diberikan kepada mahasiswa akuntansi. Rujukan yang bersifat ke arah positif ataupun negatif dari keluarga dan teman kemungkinan dapat membentuk perilaku dari mahasiswa itu sendiri (Muhammad Bimo Yudhantoko, 2013). Hasil penelitian yang dilakukan oleh (Naraika Naminingsih, 2017) menunjukkan bahwa lingkungan teman dan keluarga berpengaruh signifikan terhadap pemilihan karir akuntan publik.

$\mathrm{H}_{6}$ : Teman dan keluarga berpengaruh positif terhadap pemilihan karir sebagai akuntan publik.

\section{METODE PENELITIAN}

Penelitian ini menggunakan pendekatan kuantitatif yang berbentuk asosiatif. Penelitian asosiatif bertujuan untuk mengetahui hubungan antara dua variabel atau lebih. 


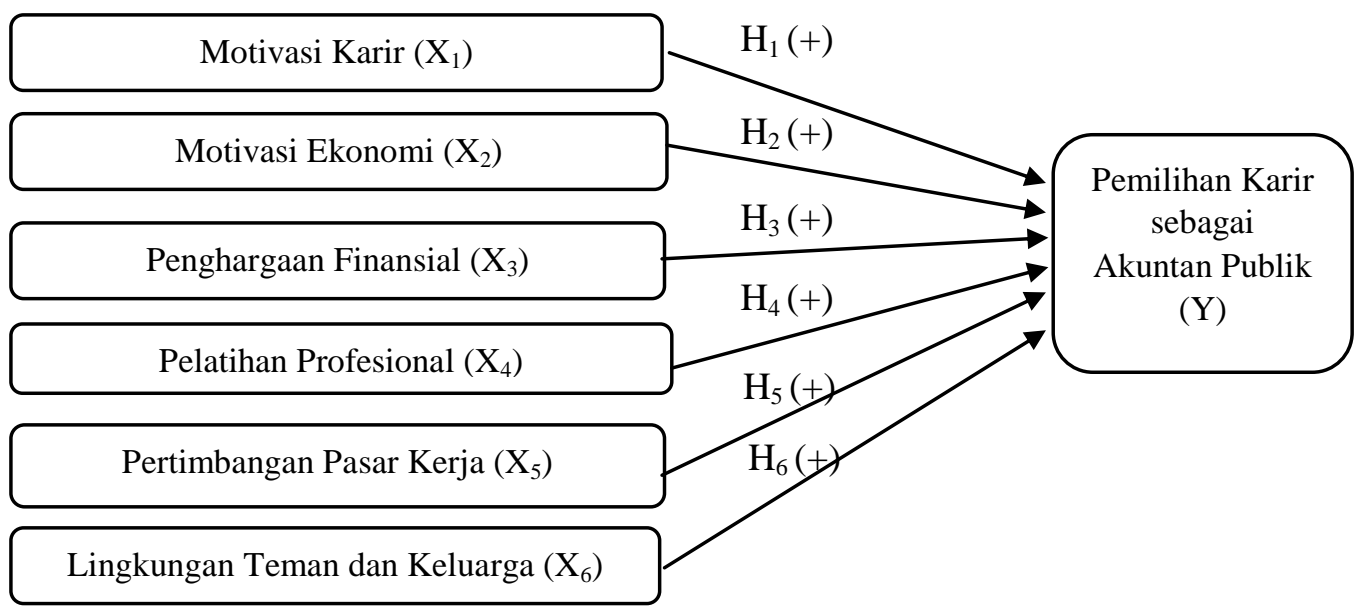

Sumber: Data diolah, 2018

\section{Gambar 1. Desain Penelitian}

Penelitian ini dilakukan pada mahasiswa jurusan akuntansi program reguler angkatan 2015, Fakultas Ekonomi dan Bisnis Universitas Udayana yang beralamat di Jalan P.B. Sudirman Denpasar. Objek pada penelitian ini adalah mahasiswa semester akhir (semester 7) jurusan akuntansi program reguler Fakultas Ekonomi dan Bisnis Program Reguler Universitas Udayana. Variabel terikat dalam penelitian ini adalah Pemilihan Karir sebagai Akuntan Publik (Y). Variabel bebas dalam penelitian ini adalah Motivasi Karir $\left(\mathrm{X}_{1}\right)$, Motivasi Ekonomi $\left(\mathrm{X}_{2}\right)$, Penghargaan Finansial $\left(\mathrm{X}_{3}\right)$, Pelatihan Profesional $\left(\mathrm{X}_{4}\right)$, Pertimbangan Pasar Kerja $\left(\mathrm{X}_{5}\right)$, dan Lingkungan Teman dan Keluarga $\left(\mathrm{X}_{6}\right)$.

Data kuantitatif meliputi data skor jawaban kuesioner yang terkumpul. Angkatan 2015 di Fakultas Ekonomi dan Bisnis Universitas Udayana. Pada penelitian ini data kualitatif berupa daftar pertanyaan-pertanyaan yang terdapat dalam kuesioner. Penelitian ini dalam pengolahan data menggunakan data primer dengan mengedarkan daftar pernyataan (kuesioner) yang akan diisi oleh 
responden. Berdasarkan lokasi penelitian yang bertempat di Fakultas Ekonomi dan Bisnis Program Reguler Universitas Udayana, maka dapat dilihat besarnya populasi mahasiswa jurusan akuntansi semester akhir (semester 7) yakni angkatan 2015 yang berjumlah 142 orang mahasiswa. Peneliti memilih Program Reguler untuk mempersingkat waktu dan mempermudah mencari responden. Pada penelitian ini, sampel yang diambil dari populasi menggunakan purposive sampling. Kriteria yang digunakan dalam penelitian ini yaitu mahasiswa jurusan akuntansi reguler Fakultas Ekonomi dan Bisnis Universitas Udayana angkatan tahun 2015 yang berjumlah 142 orang. Metode pengumpulan data yang digunakan dalam penelitian ini yaitu dengan menggunakan kuesioner.

Ghozali (2016) mengatakan bahwa analisis regresi linear berganda dilakukan untuk mengetahui hubungan antar lebih dari dua variabel, yaitu satu variabel sebagai variabel dependen dan beberapa variabel lainnya sebagai variabel independen dengan tingkat signifikansi $5 \%(\alpha=0,05)$. Adapun formula dari analisis regresi linear berganda dalam pengujian hipotesis ini adalah:

$Y=\alpha+\beta_{1} X_{1}+\beta_{2} X_{2}+\beta_{3} X_{3}+\beta_{4} X_{4}+\beta_{5} X_{5}+\beta_{6} X_{6}+\varepsilon$

Keterangan:

Y

: Akuntan Publik

$\alpha$

: Konstanta

$\beta 1, \beta 2, \beta 3, \beta 4, \beta 5, \beta 6$ : Koefisien Regresi

$\mathrm{X} 1 \quad$ : Motivasi Karir

X2 : Motivasi Ekonomi

X3 : Penghargaan Finansial

X4 : Pelatihan Profesional

X5 : Pertimbangan Pasar Kerja

X6 : Lingkungan Teman dan Keluarga

$\varepsilon$

: Standar error 


\section{HASIL DAN PEMBAHASAN}

Responden dari penetian ini adalah mahasiswa reguler angkatan 2015 jurusan akuntansi Fakultas Ekonomi dan Bisnis Universitas Udayana. Kuesioner yang disebarkan kepada responden sebanyak 142 eksemplar dengan tingkat pengembalian responden 100 persen. Tingkat pengembalian yang dapat dianalisis sebesar 100 persen dengan rincian sebagai berikut.

Pada tabel 1. menunjukkan bahwa jumlah kuesioner yang disebarkan kepada responden sebanyak 142 kuesioner dan yang dikembalikan sebanyak 142 kuesioner dan setelah diperiksa semua kuesioner layak digunakan pada analis selanjutnya.

\section{Tabel 1.}

Data Pengiriman dan Pengembalian Kuesioner

\begin{tabular}{|c|c|}
\hline Keterangan & Jumlah \\
\hline Total Kuesioner yang disebar & 142 \\
\hline Kuesioner yang tidak kembali & 0 \\
\hline Kuesioner yang dikembalikan & 142 \\
\hline Kuesioner yang tidak dapat digunakan & 0 \\
\hline Kuesioner yang digunakan dalam analisis & 142 \\
\hline Tingkat Pengembalian/Response Rate: & $100 \%$ \\
\hline $\begin{array}{l}\text { Kuesioner yang dikembalikan } \\
\text { Kuesioner yang disebar }\end{array} \quad \mathrm{x} 100 \%$ & \\
\hline 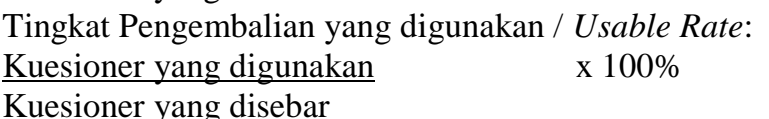 & $100 \%$ \\
\hline
\end{tabular}

Penelitian ini layak untuk dilanjutkan karena berdasarkan central limit theorem menyatakan jumlah minimal sampel untuk mencari kurva normal setidaknya mencapai nilai minimal 30 responden (Sugiyono, 2017). Karakteristik responden dapat dilihat pada Tabel 2. 
Berdasarkan Tabel 2. diatas dapat dijelaskan hal-hal sebagai berikut. Profil jenis kelamin digunakan untuk mengetahui proporsi responden pria dan wanita. Tabel 4.2 menunjukkan bahwa responden yang berjenis kelamin pria sebanyak 45 orang $(31,69 \%)$ dan responden yang berjenis kelamin wanita 97 orang $(68,31 \%)$.

Tabel 2.

Karakteristik Responden

\begin{tabular}{clcc}
\hline No & \multicolumn{1}{c}{ Keterangan } & Jumlah & Persentase (\%) \\
\hline 1. & Jenis Kelamin: & 45 & $31,69 \%$ \\
& -Laki-laki & 97 & $68,31 \%$ \\
& -Perempuan & 142 & $100 \%$ \\
& Jumlah & & \\
2. & Usia & 3 & $2,1 \%$ \\
& -20 th & 106 & $73,71 \%$ \\
& -21 th & 30 & $21 \%$ \\
& -22 th & 3 & $2,1 \%$ \\
& -23 th & 142 & $100 \%$
\end{tabular}

Sumber: Data diolah, 2019

Profil usia pada tabel 2. menunjukkan bahwa responden yang berumur 20 tahun sebanyak 3 orang $(2,1 \%)$, usia 21 tahun sebanyak 106 orang $(73,71 \%)$, usia 22 tahun sebanyak 30 orang (21\%), dan usia 23 tahun sebanyak 3 orang $(2,1 \%)$.

Tabel 3.

Hasil Uji Statistik Deskriptif

\begin{tabular}{|c|c|c|c|c|}
\hline Variabel & $\begin{array}{c}\text { Nilai } \\
\text { Minumum }\end{array}$ & $\begin{array}{c}\text { Nilai } \\
\text { Maksimum }\end{array}$ & Mean & $\begin{array}{l}\text { Standar } \\
\text { Deviasi }\end{array}$ \\
\hline Motivasi Karir $\left(\mathrm{X}_{1}\right)$ & 1,667 & 4,00 & 3,413 & 2,797 \\
\hline Motivasi Ekonomi $\left(\mathrm{X}_{2}\right)$ & 1,00 & 4,00 & 3,258 & 3,455 \\
\hline Penghargaan Finansial $\left(\mathrm{X}_{3}\right)$ & 2,00 & 4,00 & 2,993 & 1,764 \\
\hline Pelatihan Profesional $\left(\mathrm{X}_{4}\right)$ & 2,25 & 4,00 & 3,362 & 1,843 \\
\hline Pertimbangan Pasar Kerja $\left(\mathrm{X}_{5}\right)$ & 1,66 & 4,00 & 3,233 & 1,709 \\
\hline Lingkungan Teman dan Keluarga $\left(\mathrm{X}_{6}\right)$ & 1,00 & 4,00 & 2,772 & 3,142 \\
\hline $\begin{array}{l}\text { Pemilihan Karir sebagai Akuntan } \\
\text { Publik (Y) }\end{array}$ & 2,00 & 4,00 & 3,283 & 2,679 \\
\hline
\end{tabular}

Sumber: Data diolah, 2019

Berdasarkan Tabel 3. dapat dijelaskan hasilnya sebagai berikut. Variabel

Motivasi Karir $\left(\mathrm{X}_{1}\right)$ memiliki nilai minimum sebesar 1,667, nilai maksimum 4,00, 
nilai rata-rata (mean) sebesar 3,413, dan standar deviasi sebesar 2,797. Hal ini menunjukkan terjadi perbedaan dari hasil jawaban responden mengenai pemilihan karir sebagai akuntan publik terhadap nilai rata-ratanya sebesar 2,797.

Variabel Motivasi Ekonomi $\left(\mathrm{X}_{2}\right)$ memiliki nilai minimum sebesar 1,00, nilai maksimum 4,00, nilai rata-rata (mean) sebesar 3,258, dan standar deviasi sebesar 3,455. Hal ini menunjukkan terjadi perbedaan dari hasil jawaban responden mengenai pemilihan karir sebagai akuntan publik terhadap nilai rata-ratanya sebesar 3,455. Variabel Penghargaan Finansial $\left(\mathrm{X}_{3}\right)$ memiliki nilai minimum sebesar 2,00, nilai maksimum 4,00, nilai rata-rata (mean) sebesar 2,993, dan standar deviasi sebesar 1,764. Hal ini menunjukkan terjadi perbedaan dari hasil jawaban responden mengenai pemilihan karir sebagai akuntan publik terhadap nilai rata-ratanya sebesar 1,764 .

Variabel Pelatihan Profesional $\left(\mathrm{X}_{4}\right)$ memiliki nilai minimum sebesar 2,25, nilai maksimum 4,00, nilai rata-rata (mean) sebesar 3,362, dan standar deviasi sebesar 1,843. Hal ini menunjukkan terjadi perbedaan dari hasil jawaban responden mengenai pemilihan karir sebagai akuntan publik terhadap nilai rataratanya sebesar 1,843 . Variabel Pertimbangan Pasar Kerja $\left(\mathrm{X}_{5}\right)$ memiliki nilai minimum sebesar 1,66, nilai maksimum 4,00, nilai rata-rata (mean) sebesar 3,233, dan standar deviasi sebesar 1,709. Hal ini menunjukkan terjadi perbedaan dari hasil jawaban responden mengenai pemilihan karir sebagai akuntan publik terhadap nilai rata-ratanya sebesar 1,709 . 
Tabel 4.

Hasil Uji Validitas

\begin{tabular}{|c|c|c|c|c|}
\hline No. & Variabel & Kode Instrumen & Koefisien Korelasi & Keterangan \\
\hline \multirow[t]{6}{*}{1.} & Motivasi Karir $\left(\mathrm{X}_{1}\right)$ & $\mathrm{X}_{1} .1$ & 0,822 & Valid \\
\hline & & $\mathrm{X}_{1} .2$ & 0,831 & Valid \\
\hline & & $\mathrm{X}_{1.3} 3$ & 0,816 & Valid \\
\hline & & $\mathrm{X}_{1} .4$ & 0,831 & Valid \\
\hline & & $\mathrm{X}_{1} .5$ & 0,708 & Valid \\
\hline & & $\mathrm{X}_{1} .6$ & 0,829 & Valid \\
\hline \multirow[t]{6}{*}{2.} & Motivasi Ekonomi $\left(\mathrm{X}_{2}\right)$ & $\mathrm{X}_{2} .1$ & 0,743 & Valid \\
\hline & & $\mathrm{X}_{2} .2$ & 0,866 & Valid \\
\hline & & $\mathrm{X}_{2} .3$ & 0,818 & Valid \\
\hline & & $\mathrm{X}_{2} \cdot 4$ & 0,805 & Valid \\
\hline & & $\mathrm{X}_{2} .5$ & 0,842 & Valid \\
\hline & & $X_{2} .6$ & 0,922 & Valid \\
\hline \multirow[t]{3}{*}{3.} & Penghargaan Finansial $\left(\mathrm{X}_{3}\right)$ & $\mathrm{X}_{3} .1$ & 0,949 & Valid \\
\hline & & $\mathrm{X}_{3} .2$ & 0,846 & Valid \\
\hline & & $\mathrm{X}_{3} .3$ & 0,901 & Valid \\
\hline \multirow[t]{4}{*}{4.} & Pelatihan Profesional $\left(\mathrm{X}_{4}\right)$ & $\mathrm{X}_{4} .1$ & 0,829 & Valid \\
\hline & & $\mathrm{X}_{4} \cdot 2$ & 0,876 & Valid \\
\hline & & $\mathrm{X}_{4} \cdot 3$ & 0,955 & Valid \\
\hline & & $\mathrm{X}_{4} .4$ & 0,888 & Valid \\
\hline \multirow[t]{3}{*}{5.} & Pertimbangan Pasar Kerja & $\mathrm{X}_{5.1}$ & 0,830 & Valid \\
\hline & & $\mathrm{X}_{5} .2$ & 0,900 & Valid \\
\hline & & $\mathrm{X}_{5} .3$ & 0,858 & Valid \\
\hline \multirow[t]{4}{*}{6.} & Lingkungan Teman dan & $\mathrm{X}_{6} 1$ & 0,894 & Valid \\
\hline & Keluarga $\left(\mathrm{X}_{6}\right)$ & $X_{6.2} 2$ & 0,733 & Valid \\
\hline & & $X_{6} 3$ & 0,878 & Valid \\
\hline & & $X_{6 .} 4$ & 0,939 & Valid \\
\hline \multirow[t]{6}{*}{7.} & Pemilihan Karir Sebagai & Y.1 & 0,868 & Valid \\
\hline & Akuntan Publik (Y) & Y.2 & 0,768 & Valid \\
\hline & & Y.3 & 0,882 & Valid \\
\hline & & Y.4 & 0,748 & Valid \\
\hline & & Y.5 & 0,898 & Valid \\
\hline & & Y.6 & 0,857 & Valid \\
\hline
\end{tabular}

Sumber: Data diolah, 2019

Variabel Lingkungan Teman dan Keluarga $\left(\mathrm{X}_{6}\right)$ memiliki nilai minimum sebesar 1,00, nilai maksimum 4,00, nilai rata-rata (mean) sebesar 2,772, dan standar deviasi sebesar 3,142. Hal ini menunjukkan terjadi perbedaan dari hasil jawaban responden mengenai pemilihan karir sebagai akuntan publik terhadap nilai rata-ratanya sebesar 3,142. Variabel Pemilihan Karir sebagai Akuntan Publik (Y) memiliki nilai minimum 2,00, nilai maksimum 4,00, nilai rata-rata (mean) sebesar 3,283, dan standar deviasi sebesar 2,679. Hal ini menunjukkan terjadi 
perbedaan dari hasil jawaban responden mengenai pemilihan karir sebagai akuntan publik terhadap nilai rata-ratanya sebesar 2,679. Berdasarkan Tabel 4 . dapat diketahui bahwa instrument pada setiap variabel dalam penelitian ini telah memenuhi syarat validitas, karen nilai korelasi setiap instrument lebih besar dari 0,30 .

Tabel 5.

Hasil Uji Reliabilitas

\begin{tabular}{lcc}
\hline \multicolumn{1}{c}{ Variabel } & Nilai Cronbach's Alpha & Keterangan \\
\hline Motivasi Karir $\left(\mathrm{X}_{1}\right)$ & 0,890 & Reliabel \\
Motivasi Ekonomi $\left(\mathrm{X}_{2}\right)$ & 0,908 & Reliabel \\
Penghargaan Finansial $\left(\mathrm{X}_{3}\right)$ & 0,881 & Reliabel \\
Pelatihan Profesional $\left(\mathrm{X}_{4}\right)$ & 0,907 & Reliabel \\
Pertimbangan Pasar Keja $\left(\mathrm{X}_{5}\right)$ & 0,828 & Reliabel \\
Lingkungan Teman dan Keluarga $\left(\mathrm{X}_{6}\right)$ & 0,887 & Reliabel \\
Pemilihan Karir sebagai Akuntan Publik $(\mathrm{Y})$ & 0,911 & Reliabel \\
\hline
\end{tabular}

Sumber: Data diolah, 2019

Berdasarkan Tabel 5. bahwa semua instrument penelitian dinyatakan reliabel karena masing-masing variabel memiliki nilai cronbach's alpha <0,7.

Tabel 6.

Hasil Uji Normalitas

\begin{tabular}{ccc}
\hline Model & N & Asymp.Sig.(2-tailed) \\
\hline Regresi & 142 & 0,356 \\
\hline
\end{tabular}

Sumber: Data diolah, 2019

Berdasarkan Tabel 6. diatas dapat dilihat bahwa angka probabilitas atau Asymp.Sig (2-tailed) menunjukkan nilai 0,356 yakni lebih besar dari 0,05 yang artinya bahwa seluruh data dapat dikatakan berdistribusi normal. 
Tabel 7.

Hasil Uji Multikolinieritas

\begin{tabular}{lcc}
\hline \multicolumn{1}{c}{ Variabel } & \multicolumn{2}{c}{ Collinearity Statistic } \\
\cline { 2 - 3 } & Tolerance & VIF \\
\hline Motivasi Karir $\left(\mathrm{X}_{1}\right)$ & 0,430 & 2,325 \\
Motivasi Ekonomi $\left(\mathrm{X}_{2}\right)$ & 0,506 & 1,975 \\
Penghargaan Finansial $\left(\mathrm{X}_{3}\right)$ & 0,435 & 2,301 \\
Pelatihan Profesional $\left(\mathrm{X}_{4}\right)$ & 0,276 & 3,624 \\
Pertimbangan Pasar Kerja $\left(\mathrm{X}_{5}\right)$ & 0,406 & 2,462 \\
Lingkungan Keluarga dan Teman $\left(\mathrm{X}_{6}\right)$ & 0,550 & 1,819 \\
\hline Sumber: Data diolah, 2019 & &
\end{tabular}

Berdasarkan Tabel 7. dapat dilihat bahwa hasil uji multikolinieritas menunjukkan bahwa masing-masing variabel bebas memiliki nilai tolerance dan nilai VIF dari masing-masing variabel bebas tersebut.

Tabel 8.

Hasil Uji Heteroskedastisitas

\begin{tabular}{lcl}
\hline \multicolumn{1}{c}{ Variabel } & Sig. & \multicolumn{1}{c}{ Keterangan } \\
\hline Motivasi Karir $\left(\mathrm{X}_{1}\right)$ & 0,324 & Bebas Heteroskedastisitas \\
Motivasi Ekonomi $\left(\mathrm{X}_{2}\right)$ & 0,157 & Bebas Heteroskedastisitas \\
Penghargaan Finansial $\left(\mathrm{X}_{3}\right)$ & 0,336 & Bebas Heteroskedastisitas \\
Pelatihan Profesional $\left(\mathrm{X}_{4}\right)$ & 0,713 & Bebas Heteroskedastisitas \\
Pertimbangan Pasar Kerja $\left(\mathrm{X}_{5}\right)$ & 0,303 & Bebas Heteroskedastisitas \\
Lingkungan Teman dan Keluarga $\left(\mathrm{X}_{6}\right)$ & 0,210 & Bebas Heteroskedastisitas
\end{tabular}

Sumber: Data diolah, 2019

Berdasarkan Tabel 8 diketahui nilai signifikansi masing-masing variabel bebas lebih besar dari 0,05 sehingga dapat disimpulkan bahwa model regresi dalam penelitian ini bisa bebas dari gejala heteroskedastisitas.

Analisis regresi linier berganda digunakan untuk memecahkan rumusan masalah yang ada, yaitu untuk melihat pengaruh antara dua variabel atau lebih. Hasil analisis regresi linier berganda disajikan pada Tabel 9. sebagai berikut. Berdasarkan Tabel 9. diatas diperoleh suatu persamaan regresi sebagai berikut. $Y=1,503+0,140 X_{1}+0,124 X_{2}+0,186 X_{3}+0,413 X_{4}+0,333 X_{5}+0,224 X_{6}+\varepsilon$ 
Tabel 9.

Hasil Analisis Regresi Linier Berganda

\begin{tabular}{|c|c|c|c|c|c|}
\hline \multirow[t]{2}{*}{ Model } & \multicolumn{2}{|c|}{$\begin{array}{l}\text { Unstandardized } \\
\text { Coefficients }\end{array}$} & \multirow{2}{*}{$\begin{array}{c}\text { Standardized } \\
\text { Coefficients }\end{array}$} & \multirow[t]{2}{*}{$\mathrm{t}$} & \multirow[t]{2}{*}{ Sig } \\
\hline & B & Std. Error & & & \\
\hline (Constant) & 1,503 & 0,850 & & 1,769 & 0,079 \\
\hline Motivasi Karir $\left(\mathrm{X}_{1}\right)$ & 0,140 & 0,057 & 0,146 & 2,465 & 0,015 \\
\hline Motivasi Ekonomi $\left(\mathrm{X}_{2}\right)$ & 0,124 & 0,042 & 0,160 & 2,929 & 0,004 \\
\hline Penghargaan Finansial $\left(\mathrm{X}_{3}\right)$ & 0,186 & 0,090 & 0,123 & 2,079 & 0,039 \\
\hline Pelatihan Profesional $\left(\mathrm{X}_{4}\right)$ & 0,413 & 0,108 & 0,284 & 3,834 & 0,000 \\
\hline Pertimbangan Pasar Kerja $\left(\mathrm{X}_{5}\right)$ & 0,333 & 0,096 & 0,212 & 3,472 & 0,001 \\
\hline $\begin{array}{l}\text { Lingkungan Teman dan Keluarga } \\
\left(\mathrm{X}_{6}\right)\end{array}$ & 0,224 & 0,045 & 0,262 & 4,994 & 0,000 \\
\hline Adjusted $\mathrm{R}^{2}$ & & & & & 0,786 \\
\hline $\mathrm{F}$ & & & & & 87,405 \\
\hline Sig. F & & & & & 0,000 \\
\hline
\end{tabular}

Sumber: Data diolah, 2019

Persamaan regresi tersebut dapat diinterprestasikan sebagai berikut: Nilai konstanta $(\alpha)$ memiliki arti jika variabel motivasi karir, motivasi ekonomi $\left(\mathrm{X}_{1}\right)$, penghargaan finansial $\left(\mathrm{X}_{2}\right)$, pelatihan profesional $\left(\mathrm{X}_{3}\right)$, pertimbangan pasar kerja $\left(\mathrm{X}_{4}\right)$, dan lingkungan teman dan keluarga $\left(\mathrm{X}_{6}\right)$ dinyatakan konstan, maka sudah ada peningkatan keinginan mahasiswa untuk memilih berkarir sebagai akuntan publik.

Nilai koefisien regresi variabel motivasi karir $\left(\beta_{1}\right)$ menunjukkan apabila meningkatnya motivasi karir dengan anggapan variabel lainnya konstan, maka keinginan mahasiswa untuk memilih berkarir sebagai akuntan publik cenderung meningkat. Nilai koefisien regresi variabel motivasi ekonomi $\left(\beta_{2}\right)$ menunjukkan apabila meningkatnya kenaikan motivasi ekonomi dengan anggapan variabel lainnya konstan, maka keinginan mahasiswa untuk memilih berkarir sebagai akuntan publik cenderung meningkat.

Nilai koefisien regresi variabel penghargaan finansial $\left(\beta_{3}\right)$ menunjukkan apabila meningkatnya kenaikan penghargaan finansial dengan anggapan variabel 
lainnya konstan, maka keinginan mahasiswa untuk memilih berkarir sebagai akuntan publik cenderung meningkat. Nilai koefisien regresi variabel pelatihan profesional $\left(\beta_{4}\right)$ menunjukkan apabila meningkatnya kenaikan pelatihan profesional dengan anggapan variabel lainnya konstan, maka keinginan mahasiswa untuk memilih berkarir sebagai akuntan publik cenderung meningkat. Nilai koefisien regresi variabel pertimbangan pasar kerja $\left(\beta_{5}\right)$ menunjukkan apabila meningkatnya kenaikan pertimbangan pasar kerja dengan anggapan variabel lainnya konstan, maka keinginan mahasiswa untuk memilih berkarir sebagai akuntan publik cenderung meningkat.

Berdasarkan Tabel 9. menunjukkan bahwa nilai Adjusted $R$ Square adalah 0,786 atau $78,6 \%$ ini artinya sebesar $78,6 \%$ variasi pemilihan karir sebagai akuntan publik dipengaruhi oleh motivasi karir, motivasi ekonomi, penghargaan finansial, pelatihan profesional, pertimbangan pasar kerja, lingkungan teman dan keluarga. Sedangkan sisanya sebesar $21,4 \%$ dijelaskan oleh faktor lain yang tidak dimasukkan dalam model penelitian ini.

Hasil analisis menunjukkan koefisien regresi motivasi karir memiliki tanda positif. Hal ini menunjukkan semakin besar motivasi karir, menyebabkan pemilihan karir sebagai akuntan publik semakin meningkat. Hasil ini mendukung hipotesis pertama $\left(\mathrm{H}_{1}\right)$ yang menyatakan bahwa motivasi karir berpengaruh positif pada pemilihan karir sebagai akuntan publik. Artinya dengan semakin tinggi motivasi karir, maka akan tinggi pula pemilihan karir sebagai akuntan publik.

Hasil penelitian menunjukkan adanya hubungan antara motivasi karir dengan pemilihan karir sebagai akuntan publik. Mahasiswa akuntansi yang 
memilih profesi akuntan publik diharapkan pilihan karir yang ada pada saat ini dapat menjadikan seseorang yang profesional dalam bidangnya sehingga yang diinginkan akan tercapai sesuai dengan harapannya.

Teori kebutuhan McClelland menyatakan bahwa salah satu tingkat kebutuhan manusia adalah kebutuhan untuk kekuasaan (Robbins \& Judge, 2015). Mahasiswa akuntansi cenderung memilih akuntan publik sebagai pemilihan karirnya karena menganggap dapat meningkatkan kemampuan pribadinya dalam rangka mencapai kedudukan, jabatan, karir yang lebih baik dibandingkan dengan profesi akuntan lainnya. Penelitian ini sejalan dengan penelitian (Warsitasari \& Astika, 2017), motivasi karir mempunyai pengaruh positif terhadap pemilihan karir sebagai akuntan publik. Hasil pengujian hipotesis menunjukkan variabel motivasi ekonomi berpengaruh positif terhadap pemilihan karir sebagai akuntan publik. Hasil penelitian ini sejalan dengan hipotesis kedua $\left(\mathrm{H}_{2}\right)$ yaitu motivasi ekonomi berpengaruh positif terhadap pemilihan karir sebagai akuntan publik. Artinya semakin tinggi motivasi ekonomi yang dimiliki mahasiswa akuntansi maka semakin tinggi pula pemilihan karir sebagai akuntan publik.

Hasil penelitian menunjukkan adanya hubungan antara motivasi ekonomi dengan pemilihan karir sebagai akuntan publik. Teori motivasi yang diungkapkan oleh (Robbins \& Judge, 2015) terdapat tiga hubungan yang memotivasi individu dan salah satunya yaitu hubungan imbalan-sasaran pribadi, hubungan ini menjelaskan sampai sejauh mana imbalan dalam suatu organisasi memenuhi sasaran atau kebutuhan pribadi individu, serta potensi daya tarik imbalan bagi individu tersebut. Dengan adanya motivasi ekonomi, mahasiswa akuntansi yang 
memilih karir menjadi akuntan publik lebih mengharapkan penghargaan finansial. Penelitian ini sejalan dengan penelitian (Warsitasari \& Astika, 2017), motivasi ekonomi mempunyai pengaruh positif terhadap pemilihan karir sebagai akuntan publik.

Hasil analisis menunjukkan koefisien regresi penghargaan finansial memiliki tanda positif. Hal ini menunjukkan semakin besar penghargaan finansial, menyebabkan pemilihan karir sebagai akuntan publik semakin meningkat. Hasil ini mendukung hipotesis pertama $\left(\mathrm{H}_{3}\right)$ yang menyatakan bahwa penghargaan finansial berpengaruh positif pada pemilihan karir sebagai akuntan publik. Artinya mahasiswa yang memilih karir sebagai akuntan publik akan meningkat seiring dengan meningkatnya penghargaan finansial.

Hasil penelitian menunjukkan adanya hubungan antara penghargaan finansial dengan pemilihan karir sebagai akuntan publik. Teori pengharapan Vroom mengatakan bahwa penilaian kinerja yang baik akan mendorong imbalan organisasi seperti bonus, kenaikan penghargaan gaji/finansial atau promosi dan imbalan tersebut akan memenuhi sasaran pribadi karyawan tersebut. Mahasiswa akuntansi yang memilih karir menjadi akuntan publik lebih mengharapkan penghargaan finansial/gaji jangka panjang, gaji awal yang lebih tinggi dan kenaikkan penghargaan finansial yang cepat. Hasil penelitian ini sejalan dengan penelitian yang dilakukan oleh (Yanti, 2014), penghargaan finansial mempunyai pengaruh positif terhadap pemilihan karir sebagai akuntan publik.

Hasil pengujian hipotesis menunjukkan variabel pelatihan profesional berpengaruh positif pada pemilihan karir akuntan publik. Hasil ini mendukung 
hipotesis ke-empat $\left(\mathrm{H}_{4}\right)$ yang menyatakan bahwa pelatihan profesional berpengaruh positif pada pemilihan karir sebagai akuntan publik. Artinya dengan semakin mahasiswa mempertimbangkan banyak pelatihan profesional yang dilaksanakan maka semakin tinggi pula pemilihan karir sebagai akuntan publik.

Pelatihan profesional berpengaruh signifikan pada pemilihan karir sebagai akuntan publik. Hal ini sesuai dengan penelitian (Naraika Naminingsih, 2017) yaitu mahasiswa beranggapan bahwa pelatihan profesional merupakan suatu pembekalan dan peningkatan keahlian yang diberikan oleh suatu organisasi baik bagi calon karyawan ataupun karyawan tetap, dan hal tersebut akan memberikan manfaat secara langsung bagi karyawan dan calon karyawan. Profesi yang memiliki pelatihan profesional yang baik akan menjadi suatu daya tarik bagi profesi tersebut.

Hasil penelitian hipotesis menunjukkan variabel pertimbangan pasar kerja berpengaruh positif pada pemilihan karir sebagai akuntan publik. Hasil ini mendukung hipotesis kelima $\left(\mathrm{H}_{5}\right)$ yang menyatakan bahwa pertimbangan pasar kerja berpengaruh positif pada pemilihan karir sebagai akuntan publik. Artinya semakin mahasiswa mempertimbangkan keamanan lebih terjamin, lapangan kerja mudah diketahui dan pekerjaan yang mudah diperoleh maka semakin tinggi minat mahasiswa memilih karir sebagai akuntan publik.

Hasil penelitian menunjukkan adanya hubungan antara pertimbangan pasar kerja dengan pemilihan karir sebagai akuntan publik. Teori Hierarki Maslow mengemukakan hipotesis bahwa dalam setiap diri manusia terdapat hierarki lima kebutuhan salah satunya adalah keselamatan dan keamanan. Mahasiswa akuntansi 
cenderung memilih akuntan publik sebagai pemilihan karirnya karena dengan informasi semakin banyaknya perusahaan semakin banyak dicari dan hal ini menyebabkan semakin banyak peluang kerja yang ditawarkan (Talamaosandi, 2016). Hasil penelitian ini sejalan dengan penelitian yang dilakukan (Warsitasari \& Astika, 2017), pertimbangan pasar kerja mempunyai pengaruh positif terhadap pemilihan karir sebagai akuntan publik.

Hasil penelitian hipotesis menunjukkan variabel lingkungan teman dan keluarga berpengaruh positif pada pemilihan karir sebagai akuntan publik. Hasil ini mendukung hipotesis kelima $\left(\mathrm{H}_{6}\right)$ yang menyatakan bahwa lingkungan teman dan keluarga berpengaruh positif pada pemilihan karir sebagai akuntan publik. Artinya semakin mahasiswa mempertimbangkan lingkungan teman dan keluarga, maka akan semakin tinggi minat mahasiswa memilih karir sebagai akuntan publik.

Keluarga melalui aspirasinya membantu perkembangan pemilihan karir dengan memberikan dukungan dan sumber daya konstruktif yang bisa digunakan mahasiswa dalam pengambilan keputusan karir. Hasil penelitian ini sejalan dengan penelitian (Naraika Naminingsih, 2017), yang menyatakan bahwa keluarga dan teman menjadi salah satu faktor penting yang dipertimbangkan mahasiswa akuntansi dalam pemilihan karir sebagai akuntan publik.

\section{SIMPULAN}

Berdasarkan hasil analisis dan pembahasan, maka dapat disimpulkan seperti berikut ini. Motivasi karir berpengaruh positif pada pemilihan karir sebagai 
akuntan publik. Hal ini menunjukkan bahwa dengan adanya motivasi karir dalam diri mahasiswa maka mahasiswa tersebut dapat memotivasi dirinya sendiri untuk menjadi seseorang yang profesional dalam bidangnya sehingga karir yang diinginkan akan tercapai sesuai dengan tujuannya. Motivasi ekonomi berpengaruh positif pada pemilihan karir sebagai akuntan publik. Hal ini menunjukkan bahwa dengan adanya motivasi ekonomi dapat menimbulkan dorongan dalam diri seseorang untuk meningkatkan kemampuan pribadi demi mencapai penghargaan finansial/gaji yang diinginkan.

Penghargaan finansial berpengaruh positif pada pemilihan karir sebagai akuntan publik. Mahasiswa akuntansi yang memilih karir menjadi akuntan publik mengharapkan gaji yang adil yaitu sesuai dengan pengorbanan yang dilakukan serta layak dan wajar yaitu, sesuai dengan standar pemenuhan kebutuhan hidup dan memperoleh penghargaan finansial langsung maupun tidak langsung.

Pelatihan profesional berpengaruh positif pada pemilihan karir sebagai akuntan publik. Hal ini meyakinkan bahwa pelatihan profesional memberikan pembekalan dan peningkatan keahlian yang diberikan oleh suatu organisasi bagi calon karyawan nantinya. Pertimbangan pasar kerja berpengaruh positif pada pemilihan karir sebagai akuntan publik. Mahasiswa akuntansi yang memilih karir sebagai akuntan publik menganggap bahwa keamanan kerja dan profesinya lebih aman dibandingkan dengan profesi akuntan lainnya. Lingkungan teman dan keluarga berpengaruh positif pada pemilihan karir sebagai akuntan publik. Hal ini menunjukkan bahwa lingkungan teman dan keluarga dengan memberikan 
dukungan dan sumber daya konstruktif yang bisa digunakan dalam pengambilan keputusan karir.

Adapun saran yang diberikan untuk penelitian yang akan datang sebagai berikut. Bagi Calon Akuntan, hasil penelitian ini dapat sebagai bahan acuan dalam penelitian yang sama dimasa yang akan datang, sehingga hasil penelitian tersebut akan menjadi lebih sempurna. Bagi lembaga yang mempekerjakan tenaga akuntan, diharapkan dapat mengerti apa yang dipertimbangkan calon akuntan dalam memilih karir dan juga untuk lebih memotivasi para akuntan yang sudah bekerja di lembaganya.

\section{REFERENSI}

Afaq Ahmed, K., Sharif, N., \& Ahmad, N. (2017). Factors Influencing Students' Career Choices: Empirical Evidence from Business Students. Journal of Southeast Asian Research, 1-15. https://doi.org/10.5171/2017.718849

Alfrido, F. (2014). Pengaruh Motivasi Diri dan Persepsi Mengenai Profesi Akuntan Publik Terhadap Minat Menjadi Akuntan Publik pada Mahasiswa Akuntansi Fakultas Ekonomi Universitas Negri Yogyakarta. Nominal, 3(2).

Alimah, N., \& Agustina, L. (2014). Faktor-Faktor yang Mempengaruhi Minat Mahasiswa Mengikuti Pendidikan Profesi Akuntan (PPA). Accounting Analysis Journal. https://doi.org/ISSN 2252-6765

Aryani, N. P. D., \& Erawati, N. M. (2016). Pengaruh motivasi kualitas, motivasi karir, motivasi ekonomi, dan biaya pendidikan pada minat mahasiswa mengikuti pendidikan profesi akuntansi. E-Jurnal Akuntansi, 16(1).

Asmoro, T. K. W., Wijayanti, A., \& Suhendro. (2016). Faktor-Faktor Yang Mempengaruhi Mahasiswa Akuntansi Dalam Pemilihan Karir Sebagai Akuntan Publik. Issn.

Benny, \& Yuskar. (2006). Pengaruh Motivasi Terhadap Minat Mahasiswa Untuk Mengikuti Pendidikan Profesi Akuntansi (PPAk).

Carpenter, C. ., \& Strawser, R. H. (1970). Job Preferences Selection of 
Accounting Students. Journal of Accountancy, 84-86.

Chan, A. S. (2012). Analisis Faktor - faktor yang Memengaruhi Pemilihan Karir Menjadi Akuntan Publik Oleh Mahasiswa Jurusan Akuntansi. Jurnal Ilmiah Mahasiswa Akuntansi, 1(1).

Diana Sari, M. (2015). Pengaruh Motivasi, Persepsi dan Pertimbangan Pasar Kerja Terhadap Minat Mahasiswa Akuntansi PPAk dalam Pemilihan Karir sebagai Akuntan Publik (Studi Empiris pada Universitas PPAK di Sumatra). Jom FEKON.

Ghozali, I. (2016). Aplikasi Analisis Multivariate Dengan Program IBM dan SPSS 21. In Aplikasi Analisis Multivariate dengan Pogram iIBM SPSS 21. https://doi.org/10.1016/j.tsf.2010.09.040

Hutapea, H. . (2016). The Perception of Accounting Students About The Factors Which of Career Selection.

IAPI (Institut Akuntan Publik Indonesia). (n.d.). Retrieved April 8, 2019, from https://iapi.or.id/Iapi/detail/7

Kadarisman, M. (2012). Manajemen Kompensasi. Jakarta: Rajawali Pers.

Koech, J., Bitok, J., Rutto, D., Koech, S., Okoth, J. O., Korir, B., \& Ngala, H. (2016). Factors Influencing Career Choices Among Undergraduate Students in Public Universities in Kenya: A Case Study Of University Of Eldoret. International Journal of Contemporary Applied Sciences, 3(2).

Lukman, H., \& Juniati, C. (2016). Faktor Yang Pengaruhi Pemilihan Karir Sebagai Akuntan Publik Bagi Mahasiswa PTS Wasta Dengan Pendekatan Reasoned Action Model. Jurnal Akuntansi, 20(02). https://doi.org/http://dx.doi.org/10.24912/ja.v21i2.195

Mauldin, S., Crain, J. L., \& Mounce, P. H. (2000). The Accounting Principles Instructor's Influence on Students' Decision to Major in Accounting. Journal of Education for Business, 142-148. https://doi.org/10.1080/08832320009599005

Merdekawati, D. P., \& Sulistyawati, A. I. K. A. (2011). Faktor-Faktor Yang Mempengaruhi Pemilihan Karir Akuntan Publik dan Non Akuntan Publik. Jurnal Riset Akuntansi. https://doi.org/ISSN 1693-928X

Muhamad, H., Salleh, M. M., \& Nordin, M. S. M. (2016). Factors influencing career choice of accounting students in University Putra Malaysia: Qualitative pilot study. Journal of Advanced Research in Social and Behavioural Sciences, 5(1), 25-34. 
Muhammad Bimo Yudhantoko. (2013). Persepsi Mahasiswa Akuntansi Mengenai Minat Dalam Pemilihan Karir Sebagai Akuntan Perusahaan (Studi Empiris pada Mahasiswa Akuntansi di Beberapa Universitas di Kota Semarang dan Kabupaten Kudus). E-Journal Universitas Dipenogoro.

Naraika Naminingsih, N. (2017). Pengaruh Penghargaan Finansial, Pelatihan Profesional, Pertimbangan Pasar, Teman dan Keluarga dalam Pemilihan Karir Akuntan Publik: Studi pada Mahasiswa Akuntansi Syariah di IAIN Surakarta.

Omar, M. K., Zakaria, A., Ismail, S., Sin, J. S. L., \& Selvakumar, V. (2015). Job Selection Preferences of Accounting Students in Malaysian Private Universities. Procedia Economics and Finance. https://doi.org/10.1016/S2212-5671(15)01135-1

Pratama, A. (2017). Why Do Accounting Students Choose a Career in Accountancy? An Exploratory Study in Bandung City, West Java, Indonesia. Review of Integrative Business and Economics ResearchOnlineCDROM, 6(2), 393-407.

Rahayu, S. (2003). Persepsi Mahasiswa Akuntansi Mengenai Faktor-faktor yang Memengaruhi Pemilihan Karir, Simposium Nasional Akuntansi IV. In Simposium Nasional Akuntansi IV (pp. 821-838).

Rahmat, F., \& Zulaikha. (2013). Analisis Faktor-Faktor yang Memengaruhi Pemilihan Karir Mahasiswa Akuntansi (Studi Empiris Mahasiswa Akuntansi di Perguruan Tinggi di Semarang). Jurnal Ekonomi Dan Kewirausahaan, 2(4).

Robbin, S. P. (2011). Behaviour in Organization. NJ: Prantice Hall.

Robbins, \& Judge. (2015). Perilaku Organisasi. Jakarta: Salemba Empat.

Rohmatullah, Siti, N. T. H., \& Erni Sulindawati, N. L. G. (2014). Pengaruh Persepsi Mahasiswa Akuntansi Mengenai Lingkungan Kerja Auditor Terhadap Pilihan Karirnya Sebagai Auditor. E-Journal S1 Akuntansi Universitas Pendidikan Ganesha, 2(1).

Samsuri, A. S. B., Arifin, T. R. B. T., \& Hussin, S. B. (2016). Perception of Undergraduate Accounting Students towards Professional Accounting Career. International Journal of Academic Research in Accounting, Finance and Management Sciences, (3). https://doi.org/10.6007/IJARAFMS/v6$\mathrm{i} 3 / 2173$

Stolle, S. . (1976). Student's View of The Public and Industrial Accountant. Journal of Accountancy, 106-109. 
Sugiyono. (2017). Metode Penelitian Bisnis. Bandung: Alfabeta. https://doi.org/10.1016/j.maturitas.2005.10.005

Talamaosandi. (2016). Pengaruh Lingkungan Kerja, Nilai-Nilai Sosial, Pertimbangan Pasar Kerja dan Personalitas Pada Pemilihan Karir Sebagai Akuntan Publik. Skripsi Akuntansi. Fakultas Ekonomi Dan Bisniis Universitas Udayana.

Ulva, A. (2016). Faktor-Faktor Yang Mempengaruhi Mahasiswa Akuntansi di Kota Surabaya Dalam Pemilihan Karir Sebagai Akuntan Publik.

Utama, M. S. (2014). Aplikasi Analisis Kuantitatif (8th ed.). Denpasar: Fakultas Ekonomi dan Bisnis Universitas Udayana.

Utami, N. (2016). Faktor-faktor Yang Mempengaruhi Pemilihan Karir Aakuntan Publik (Studi Kasus Mahasiswa Program Studi Akuntansi Fakultas Ekonomi dan bisnis di Universitas Muhammadiyah Surakarta).

Warsitasari, I. A. T. S., \& Astika, I. B. P. (2017). Pengaruh Motivasi, Persepsi, Penghargaan Finansial, Pasar Kerja dan Pengakuan Profesional Pada Pemilihan Karir Akuntan Publik. Jurnal Akuntansi Universitas Udayana, 21(3).

Wheeler, K. . (1983). Perceptions of Labour Market Variables by College Student in Business, Education, and Psychology. Journal of Vocational Behavior, 22, $1-11$.

Widiatami, A. K. (2013). Determinan Pilihan Karir pada Mahasiswa Akuntansi (studi Empiris pada Mahasiswa Akuntansi S1 Universitas Diponegoro). Jurnal Akuntansi, 3(2013), 1-11.

Widyastuti, S. (2004). Pengaruh Motivasi Terhadap Minat Mahasiswa Untuk Mengikuti Pendidikan Profesi Akuntansi.

Yanti, N. (2014). Analisis Faktor-Faktor yang Memengaruhi Mahasiswa Akuntansi dalam Pemilihan Karir Menjadi Akuntan Publik (Studi empiris pada Perguruan Tinggi Negeri dan Swasta di Pekanbaru). Jurnal Akuntansi, 1(2), 2014.

Zotorvie, J. S. T. (2016). Determinants of Career Choice among Students of Institute of Chartered Accountants (Ghana). European Scientific Journal. https://doi.org/10.19044/esj.2016.v12n31p255 